\title{
6 Culturalism, Classism, and the Politics of Redistribution
}

My study distances itself from the black nationalist agendas of the Black Revolutionary Theatre, Afrocentrism and the Black Women's Renaissance. I do, however, recognize the double-edged character of nationalism. This was emphasized by Elleke Boehmer in Stories of Women: Gender and Narrative in the Postcolonial Nation, when she stated that "nationalism can be deployed to reactionary and progressive ends; as a means of self-determination and social justice for an entire people and a channel of their at once national and international consciousness and as an oppressive formation run in the interests of an elite" (4). The essays collected in this seminal study by Boehmer lean towards a positive evaluation of nationalism which "historically not only offered important ways of recovering self and reclaiming cultural integrity after colonial occupation, but has also remained an important ground for transforming political and economic conditions, forging identity and achieving social justice" (ibid.). Likewise, my own reading of the fiction of the BWR has attempted to shed light on both the achievements and the pitfalls of the womanist version of the black aesthetic and black cultural nationalism. In this concluding chapter, however, I would like to look back on the ethnographic and historical/heritage prose that the BWR produced in the 1980s from the vantage point of the contemporary political science and feminist social criticism, both of which paint a harsher picture of this body of work.

As I argued in my Introduction, the cultural nationalism of the BWR was, in Robert Carr's words, "a doctrine of crisis” (Black Nationalism 4). It called for essentialist notions of culture and positive representations of black identity as a means to mobilize African American people against cultural denigration and racial oppression. The nationalist surge in black feminist fiction of the 1980s was also a backlash against the rampant sexism that prevailed within the Black Arts Movement, but first and foremost, it was triggered by late 20th century social and political crises. ${ }^{75}$ These crises were described by Nancy Fraser as a shift from the "welfare society" that was "associated with social democracy" to "the insecurity society" that came into being in the 1980s with the resurgence of the free-market policies of global neo-liberalism ("Mapping the Feminist Imagination" 303). This decade of conservative rule in the US created for African Americans a situation of instability and disruption. I would argue that this contributed to the rise of black nationalism since it brought about an increase in discrimination, alienation, and economic and social marginality for American

75 A few books have discussed ethno-nationalism as a reaction to crises of national identity. See for example: Michael Ignatieff's Blood and Belonging: Journeys into New Nationalisms, which is about ethno-nationalism in Eastern Europe after the fall of communism; and Julia Kristeva's, Nations without Nationalism, which is about the rise of neo-Nazi groups in Germany and Eastern Europe and the continued popularity of the National Front in France. 
blacks. Under Ronald Reagan's administration, black people in America began to feel once again the pinch of reactionary racial policies that caused a rise in unemployment and a reduction in social services and educational opportunities, as well as the incarceration of black men on a massive scale. The conservative ascendancy continued in the 1990s, when the endemic brutality of the police rose to new heights, culminating in 1991 in the beating of Rodney King that marked the beginning of "zerotolerance policies" and racial profiling. The changing political climate contributed to an ever-growing sense of vulnerability in black communities, which felt that in this increasingly conservative environment the stakes were set against them. Indeed, the divisive tactic of playing the race card became a common practice in American politics; after Reagan's attack on black “welfare queens,” George H. W. Bush used adverts that featured Willie Horton ${ }^{76}$ to capitalize on radical anti-black sentiments in order to win his presidential election. This zeitgeist undoubtedly contributed to the revival and entrenchment of black nationalism. Courtney Thorsson summed up this position with respect to the BWR novels of the 1980s when she said that these "novels remake cultural nationalism to sound the alarm, to insist that the 1980s and 1990s were years of racial crisis, even though that crisis [might] be complex or hard to see. Resistance, too, remain[ed] central to ... [BWR] writers, even when this resistance [was] less visible than a civil rights march or a Black Panther patrol” (Women's Work 181).

BWR narratives certainly countered claims that America was a post-racial and color-blind country, a claim that was still being frequently and forcefully repeated under the presidency of Barak Obama and dismissed only after the triumphant emergence of the alt right under Trump. The prose of the BWR, rooted in folklore and uncompromising in its assertions of the continuing relevance of the negative slave heritage, was an attempt to shore up a cultural nation and recall the "positive particularities that may have accrued to black cultural and communal practices over time" (Nikhil Pal Singh, qtd. in Thorsson ibid.). BWR writers were tapping into the tactics that were being employed by the whole postcolonial world, which saw nationalism as a powerful "anti-systemic movement" that could combat racism, marginality, and inequity (Wallerstein, "New Revolts"). In multicultural America, too, "the idea of the nation was a powerful vehicle for harnessing anticolonial energies ... at all ... levels": political, intellectual, emotional (Loomba, Colonialism 155).

The overwhelming majority of BWR novels of the 1980s, particularly those written by African American rather than African Caribbean authors, engaged with issues, of "ethno-national" importance. Contrary to 1970s social protest novels, this 1980 s fiction was less focused on depicting the circumcised social conditions and economic

76 The so-called “Revolving Door” ad was used by George H. W. Bush when he ran for President in 1988 to discredit his opponent, Michael Dukakis. As a governor, Dukakis had supported a prison furlough program which made it possible for Willie Horton, serving a life sentence for murder, to leave a Massachusetts prison on a weekend furlough, escape and rape a woman. 
exploitation of black people; instead, it overtly celebrated the cultural essence of the black nation. At the time when the nation seemingly fell out of fashion, these black women writers sought to re-create what Renan called "a soul, a spiritual principle" for their nation ("What is a Nation?" 19). Consequently, in the 1980s, BWR writers were less interested in the economic and racial warfare that had dominated the literature of the 1960s and 70s; in its stead, they redirected their energies to building pride in being black and "regenerating the community from within," as Harry Reed has put it ("Toni Morrison" 52). The difference between the approach of the women of the black Renaissance to nationalist ideology and that of their male predecessors can be best illustrated by the following quote from Ntozake Shange, who said: "I have to feed the people but when I feed the people I can't give them rations, I have to give them a meal that is nurtured with love and that has particular spices for particular tastes" (Shange et al., "Artists' Dialogue” 159). The feminist version of black nationalism and the black aesthetic, as Reed has also aptly observed ("Toni Morrison" 52-53), was about creating food for the soul, rather than ensuring the mere physical survival of the community. BWR novels of the 1980s showed that imagined communities are both "territorial and social spaces" (Anderson, Imagined Communities 184), made up of folk myths, practices and rituals. They stemmed from the slave cultures of the extended Caribbean and were preserved by black foremothers and by the "community of black women writers" whom Beverly Guy-Sheftall has described as having willfully "written themselves into the national consciousness" ("Preface" xvv).

On the surface, the shift that occurred in the black feminist agenda in the 1970s and ' 80 s may seem positive, but it appears less so if viewed from the perspective of a larger, political and socio-economic perspective. It could be argued that the abrupt change in black feminist priorities and sensibilities in the 1980s reflected another much larger transition in American politics of the conservative era that Nancy Fraser called, in her 2005 article: "Mapping the Feminist Imagination: From Redistribution to Recognition to Representation," a "shift from redistribution to recognition" (300). Fraser argues here that in the late 20th century, feminism in America radically rethought its agenda. She states that in its first phase, from the post-Second-World-war years to the civil-rights era, "feminism stood in a close relation to the various "new social movements"; in the second phase, however, it "was drawn into the orbit of identity politics" (296). ${ }^{77}$ Consequently, it was no longer interested in the "problems of class distribution," becoming instead "preoccupied with culture” (ibid.). In effect, therefore, "whereas the previous generation [of feminists] pursued an expanded ideal of social equality, this one [in the 1980s and '90s] invested the bulk of its energies in

77 Fraser argues that in a third, contemporary, phase, feminism is increasingly practiced as a transnational politics. She states that “[i]n Europe and elsewhere ... feminists have discovered, and are skillfully exploiting, new political opportunities in the transnational political spaces of our globalizing world" ("Mapping the Feminist Imagination" 296). 
cultural change" (ibid. 299). This new emphasis on the politics of recognition, whose aim was to acknowledge and appreciate previously devalued cultures, coincided with a rolling back of the frontiers of the welfare state due to pressure from the global neoliberalism that was gathering momentum in the 1980s. According to Fraser:

In the fin-de-siècle context, the turn to recognition dovetailed all too neatly with a hegemonic neoliberalism that wanted nothing more than to repress all memory of social egalitarianism. The result was a tragic historical irony. Instead of arriving at a broader, richer paradigm that could encompass both redistribution and recognition, we effectively traded one truncated paradigm for another - a truncated economism for a truncated culturalism. The timing, moreover, could not have been worse. The shift to a culturalized politics of recognition occurred at precisely the moment when neoliberalism was staging its spectacular comeback. Throughout this period, academic feminist theory was largely preoccupied with debates about "difference." Pitting "essentialists" against "anti-essentialists," these disputes usefully served to reveal hidden exclusionary premises of earlier theories, and they opened gender studies to many new voices. Even at their best, however, they tended to remain on the terrain of recognition, where subordination was construed as a problem of culture and dissociated from political economy. The effect was to leave us defenseless against free-market fundamentalism, which had meanwhile become hegemonic. Effectively mesmerized by the politics of recognition, we unwittingly diverted feminist theory into culturalist channels at precisely the moment when circumstances required redoubled attention to the politics of redistribution. (Ibid. 297)

Fraser claims that the fin-de-siècle culturalism was therefore a "regressive" politics that played into the hands of the neo-liberal establishment in the United States (ibid.), which was "perfecting its own strategic deployment of a regressive cultural politics to distract attention from its regressive politics of redistribution" (ibid. 302).

That strategy can be summarized in one term: multiculturalism. With its emphasis on essentialism, separatism, unity, and "sensitivity to difference" vis-à-vis other ethnic groups, feminism became a "version of multiculturalism with all its problematics" (Yuval-Davis, Gender \& Nation 118). In other words, it could be argued that the cultural turn in feminism colluded with a neoliberal multicultural politics whose objective was to valorize ethnic and cultural difference at the expense of the struggle for social and economic equality. The cultural turn convinced black women writers and feminist critics that they should invest it in a nationalist outlook. Consequently, a politicized black culture as identity politics became the principal concern for feminist writers and critics.

Fraser is of the opinion that it may have been a coincidence that the "shift from redistribution to recognition" in feminism occurred simultaneously with the political shift from the "welfare society" to "the insecurity society," but many theorists of ethnicity, multiculturalism and ethno-nationalism see both shifts as part of the neo-liberal grand design. Yuval-Davis has observed that in fact the "culturalized discourses" of ethnic nationalisms "emerged with national and international policies of multiculturalism” (ibid. 39). Werner Sollors, in The Invention of Ethnicity (1989) and Beyond Ethnicity: Consent and Descent in American Culture (1986), asserted that the neo-libe- 
ral endorsement of ethno-nationalisms was deliberately geared towards maintaining a hierarchy of culture and race. Sollors pointed out that the politics of multiculturalism, which was based on the affirmation of ethnic heritages and ethnocentric aesthetics, was actually another manifestation of neo-liberal state politics that encouraged ethnic groups to see themselves as sub-nations within the American supra-nation. He argued that the politics of recognition did not change the fact that multiculturalism always covertly privileged the white middle-class mainstream over the ethnic other, treating WASP culture as the universal standard of cultural refinement. As a consequence, the politics of recognition reinforced the center-periphery model of society by reinforcing cultural stereotypes attributed to minority cultures and consolidating existing power structures. ${ }^{78}$ In Sollors's opinion, therefore, the politics of cultural recognition was counterproductive and deeply flawed from the outset.

As Yuval-Davis has pointed out, however, when culturalism "started to emerge as a means of political empowerment," it was easy to take its positive rhetoric of recognition at face value, and it is no wonder that it had particular appeal "among marginalized groupings such as blacks and women” (Gender \& Nation 39). BWR writers were certainly caught up in this culturalist imaginary, which, in retrospect, can be seen as a strategy not entirely of their own making, and they reinvented themselves in the 1980s as "cultural workers," "archivists" or "redemptive scribes" (Mobley, Folk Roots 11). As my study has demonstrated, they invested immensely in what Nancy Fraser has called the "culture-centered politics of recognition" ("Mapping the Feminist Imagination” 296). The cult of ethnicity was nowhere more conspicuous than in the discourse of womanism that became an article of faith for most BWR writers in the 1980s. Layli Phillips stressed that "to be a womanist, one [had to] identify one's cultural roots and experience oneself as a cultural or ethnic being," ("Introduction: Womanism on Its Own” xxxvi). She added that:

Womanism detests race but loves ethnicity and culture, because the concept of race is rooted in the relations of domination and oppression, whereas ethnicity and culture are storehouses of human knowledge that contain such systemic and life-enhancing elements as ancestry, history, memory, geography, cosmology, epistemology, worldview, metaphysics, ethics, aesthetics, logic, psychology, spirituality, traditions, rituals, art, literatures, architecture, food, medicine, science, and language. In other words, culture is rich, while race is impoverished; culture is life affirming, while race is dehumanizing. (xxxvi)

78 For a critique of the multicultural social model, see also David Hollinger's Postethnic America: Beyond Multiculturalism. In this book, which was hailed as a groundbreaking proposal for healing American ethnic divisions, Hollinger argues for replacing the pluralist and divisive model of multiculturalism with a cosmopolitan model that recognizes the reality of shifting group boundaries and multiple identities. See also Richard King's Postcolonial America, and John Carlos Rowe's Post-Nationalist American Studies. 
Admittedly, such "strategic essentialism" had the positive effect of building black selfesteem, consolidating imagined communities, and mobilizing black people to resist the fallacy of a post-racial and color-blind America. On the other hand, however, as Fraser has suggested, it inadvertently helped to "subordinate social struggles to cultural struggles, [and] the politics of redistribution to the politics of recognition" ("Mapping the Feminist Imagination" 299).

The dialectic between culturalism and ethno-nationalism in the BWR also had other undesirable side-effects. As a strategy of cultural survival, the politics of recognition required strict management of ethnic boundaries. Yuval-Davis notes that in African American discourse, as in many other oppositional ethnocentric discourses, this management "[took] the form of oppositional construction or demonization" of the Other (Gender \& Nation 48), for example, Gilroy's analysis of the antagonistic relationship between African Americans and American Jews and "[demonizing] those thought to be excessively 'modern'” (Gender \& Nation 48). This tendency clearly informed Afrocentric and BWR writing. Though Afrocentrism and the BWR championed different versions of African American heritage, both targeted assimilated and westernized African Americans as the Other, whilst promoting pre-modern, Africanderived values and identities. This aversion for worldviews that were considered too "modern" and ambitions that were too worldly permeates novels such as Morrison's Tar Baby and Marshall's Praisesong for the Widow, which attack individualism, materialism, the Puritan work ethics and the ideal of bourgeois domesticity as pillars of western polity. Cliff is another good example of a writer whose fiction can be said to "reconstruct some notion of purified African culture" (Gilroy, "A Dialogue with bell hooks" 209). We can add to this list the Afrocentric distrust of practitioners and consumers of syncretic forms of popular black culture that hooks described as being "contaminated" by the white mainstream (Gilroy, "A Dialogue with bell hooks" 209). Similarly, as Trinh T Min-ha argued about postcolonial women, "[t]he search for that lost, pure, true, real, genuine, original, authentic self, [was] often situated within a process of elimination of all that ... [was] considered other, superfluous, fake, corrupted, or Westernized" ("Not You/Like You" 415). Both Afrocentrism and the late BWR favored a concept of identity that was understood as "an essential, authentic core that remain[ed] hidden to one's consciousness and that require[d] the elimination of all that is considered foreign or not true to the self" (ibid.).

When black feminism took the cultural turn in the 1980s and BWR writers and critics became "theorists of identity" (Thorsson, Women's Work 4), the most vocal advocates of the politics of recognition could be found among womanists. Womanism, which was rooted in the black folk tradition, was diametrically opposed to feminism. It endeavored to articulate a distinctively and exclusively black version of feminism by exaggerating racial differences and dissociating itself from white feminism. Womanism could be viewed a nationalist wing of black feminism that promoted racial separatism. As Patricia Hill Collins has argued, it "sits squarely in black nationalist traditions premised on the belief that blacks and whites cannot function as equals 
while inhabiting the same territory or participating in the same social institutions" (“What's in a Name?" 10). The womanist rhetoric of ethnicity, authenticity and roots made differences between African American and other women insurmountable, and boundaries between white and black feminisms more rigid (Sandoval, "U.S. Third World Feminism" 1-24). Womanism championed "racial separatism," favored female bonding among black women, and saw white feminists as "enemies" (Collins, "What's in a Name?" 11). Even though Alice Walker found many followers, the essentialism of womanism was criticized from both outside and within the black feminist movement for failing to consider the interconnectedness of women's experiences of oppression. According to Collins, whereas within African American society, womanism created opportunities to address gender imbalance and create better relationships between black women and men, outside that context, it prevented inter-racial and inter-ethnic cooperation among women ("Sisters and Brothers" 59). ${ }^{79}$ Schultermandl concludes that womanism was also "counterproductive to the building of feminist solidarities within the US academy where feminists and womanist scholars often position themselves in opposition to each other" (Transnational Matrilineage 51).

Likewise, Chicana feminists condemned all types of culturally embedded feminist counter-movements, such as womanism and yellow and red feminisms, arguing that these movements inadvertently tapped into the neo-liberal and multicultural politics of "divide and rule." Where womanists erected and defended ethnic boundaries, the so-called border-studies feminists deconstructed them by claiming a new location for post-ethnic feminism between the extreme positions of the center/periphery and Us/ Them binaries. For example, Gloria Anzaldua's autobiography, Borderlands/La Frontera: The New Mestiza (1987), proposed a hybrid model of feminist consciousness, embodied by the term "New Mestiza." This was a fragmented and inclusive self, situated at the borderland of cultural indeterminacy. Although Chicana writers and critics were also preoccupied with the issue of cultural identity, they were less concerned with the politics of redistribution, exhibiting instead a greater awareness of the fact that, as Anzaldua stated, "culture is made by those in power - men. Males make the rules and laws; women transmit them" (Borderlands 31). That was particularly true about essentialized notions of culture intent on reinforcing the multicultural status quo, with its established racial and gender relations. Unlike womanists, Chicana writers and critics attempted to represent black women from a trans-national and

\footnotetext{
79 Layli Phillips states that "[t]he three most common critiques of womanism are that (1) it allows Black women to reject feminism, minimizing the gains that Black feminists have achieved for all Black women through struggle; (2) it undermines feminist struggle by creating confusing and diversionary new terminology with ambiguous politics and little connection to activism; and (3) like white feminism, it is imperialist insofar as it privileges the views of U.S. Black women and pushes them globally onto womanists of other nations and cultures" ("Introduction" xlxii)
} 
cross-cultural perspective challenging the racially and ethnically segregated terrain of neo-liberal and multicultural America. ${ }^{80}$

Another problem with womanism's embrace of culturalism was its handling of what Helen Charles called "the difference within difference" ("Harmony, Hegemony, or Healing?" 369). Even though womanism was based on the politics of recognition, it paradoxically silenced the pleas for recognition of difference that came from within black communities themselves. According to Anna Yeatman, this is how the multicultural "politics of difference" inevitably works. It makes it imperative for "a leadership of the [minority] group" - its political elites, artists, writers, critics and educators - to "represent its homogeneity of purpose by speaking with the one authoritative voice" ("Minorities" 4). For womanists, this authoritarian voice took the form of ethnographic prose and criticism which aimed "to rally the force needed to face the multidimensional threats to ... [black] survival in the 80s" (Lorde, "Learning from the 60s" 138). The volkish tradition, which was based on "conjuring and orality combine[d] to produce an emphatically antimodern, anti-urban, and anti-textual [oral] model of community" (Dubey, Signs and Cities 170), served as a cultural repertoire of strategies of resistance and survival. It promoted the image of a "community of cultural insiders engaging in harmonious, crisis-free, acts of knowing, speaking and listening” (ibid.). As southern black regionalists, womanists believed they had an exclusive connection to the one-and-only, time-sanctioned and "women-borne" tradition of the black aesthetic. They believed in the existence of "ancient properties" - the "eternal" and authentic cultural values embedded in southern black communities presided over by wise black women. Womanist narratives of immersion indulged in metaphysical

80 Other post-national and post-ethnic studies and essay collections based on the intersection of postcolonialism, postmodernism, poststructuralism and Third World feminism that argue for creating post-ethnic alliances include: This Bridge, Called My Back: Writing by Radical Women of Color (1981), an anthology edited by Gloria Anzaldua and Cherrie Moraga, Trinh T. Minh-ha's When the Moon Waxes Red: Representation Gender Cultural Politics (1991); Chandra Talpade Mohanty and Ann Russo Lourdes Torres's Third World Women and the Politics of Feminism (1991); Ana Louise Keating's Women Reading Women Writing: Self Intervention in Paula Gunn Allen, Gloria Anzaldua and Audre Lorde (1996); Sandra Kumamoto Stanley's Other Sisterhoods: Literary Theory and US Women of Colour (1998); Inderpal Grewal and Caren Kaplan's Scattered Hegemonies: Postmodernity and Transnational Feminist Practices (1994); M. Jacqui Alexander and Chandra Talpade Mohanty's Feminist Genealogies, Colonial Legacies, Democratic Futures (1997); Caren Kaplan, Norma Alarcón and Minoo Moallem's Between Woman and Nation: Nationalisms, Transnational Feminisms, and the State (1999); Amal Amireh and Lisa Suhair Majaj's Going Global The Transnational Reception of Third World Women Writers (2000); Uma Naryan and Sandra Harding's Decentering the Center: Philosophy for a Multicultural, Postcolonial and Feminist World (2000); Chandra Talpade Mohanty's Feminism Without Borders: Decolonizing Theory, Practicing Solidarity (2003); Ella Shohat's Talking Visions: Multicultural Feminism in a Transnational Age (2001); Caren Kaplan and Inderpal Grewal's An Introduction to Women's Studies: Gender in a Transnational World (2002); and Carole R. McCann and Seung-kyung Kim's Feminist Theory Reader: Local and Global Perspectives (2009). 
speculation on the wholeness and spirituality of this timeless maternal culture and its regenerative and empowering potential. In effect, as bell hooks has noted, they established "a totalizing notion of black experience that [saw] only those folks who live[d] in segregated communities or [had] little contact with whites as authentically black” ("Revolutionary Black Women” 226).

As Helen Charles has pointed out, a corollary of Walker's "view that there can exist a [unique black] 'woman's culture"” was "the notion of an all-encompassing 'single black super-woman"” (“Harmony, Hegemony, or Healing?” 367). According to Charles, womanism failed to acknowledge that "while difference exists between the black woman and the non-black woman, it also exists between individual black women" (ibid. 373). The notion of the black super-woman, which was a foil for the "generic" woman of the second wave of feminism, was potentially as totalizing as the notion of authentic black southern culture since for womanists, black women, as "bearers of sheer, untranslatable difference" (Dubey, Signs and Cities 23), were seen as metaphors for black southern culture. Womanism refused to consider the individual positioning of black women and the fact that "within the parameters of blackness, not all black women are the same," as Charles argued, adding that "[t]hey are diverse politically, culturally, sexually; colour, caste and class-wise" ("Harmony, Hegemony, or Healing?” 369). Admittedly, many BWR novels of the 1980s, such as The Color Purple, Zami and The Gilda Stories, were radical and groundbreaking in their treatment of the taboo subject of lesbianism, seeing in lesbian relationships a special kind of female bonding that was empowering for women. On the score of class, gender and generational divisions, however, womanism gave rise to what Trinh T. Minh-ha called, in a different context, an "essentialist hegemony" that "work[ed] at leveling out differences and at standardizing contexts and expectations in the smallest details of daily lives" ("Not You/Like You" 416).

This drive towards the "imposition of sameness" (ibid.), which the ideal of the black super-woman entailed, was nowhere more conspicuous than in discourse on mothering and matriliny in the 1980s. The 1980s saw a spectacular reversal in womanist thinking about mothers and their role in preserving and conveying the cultural/ ethnic essence of black identity. The black mother in 1970s feminist fiction was a deeply ambiguous figure: self-loathing and negligent like Pauline Breedlove in The Bluest Eye; self-sacrificing but ultra-conservative like Meridian's mother; crassly materialistic like Selina in Brown Girl, Brownstones; helpless and absent as in the The Third Life of Grange Copeland; or toxic and unforgiving like Corregidora's women. As a consequence, younger women, such as Meridian, Sula and Ursa, were represented as being increasingly averse to motherhood, seeing in it an "oppressive formation" that threatened to derail their lives. In the womanist decade, by contrast, motherhood was once again idealized as the core of national/cultural identity. Wise grandmothers, "community" mothers and female griots, conjurers and storytellers played a pivotal role as "reproducers of narratives of the [nation]" (Yuval-Davis, Gender \& Nation 39). Black women writers created formidable female characters, such as Thérèse, Mama Day, 
Baby Suggs, Aunt Cuney and the mythical Nanny, in order to "imagine the nation into being," to use Boehmer's expression (Stories of Women 15). Their novels hailed these foremothers as "semiotic sites" and archivists of the "myth-memories" of the African Caribbean motherland (Smith A.D.). These maternal characters can be described not only as "custodians of traditions" and "the root of culture and values" (Wisker, Postcolonial 140), but also as ethnic “territory markers” (Yuval-Davis, Gender \& Nation 39) and "boundary subject[s]" (Kristeva, Nations 35). In other words, they function in the narratives as benchmarks against which the aspirations, dreams and moral choices of all the black female characters were measured. In this way, womanism created a moralistic ideology that subsumed the multiplicity of black women's lives into one universal category of generic black womanhood that valued black women primarily as wise "culture-bearing” mothers or reverent and obedient daughters.

As Susan Stanford Friedman has argued in "Creativity and the Childbirth Metaphor," such "biologic poetics," in which motherhood is privileged as a source of creativity and female activism, is a special kind of essentialism that runs "the risk of biological determinism" (390). She adds that:

It theoretically privileges motherhood as the basis of all creativity, a position that symbolically excludes women without children and all men. It also tends toward a prescriptive poetic that potentially narrows the range of language and experience open to women writers. (Ibid.)

None of the novels that have been discussed in this study, except for those by Jamaica Kincaid, are entirely free of "biologic poetics." Even those female characters who do not expressly equate the black mother with the black nation, like Dana (Kindred) and Gilda (The Gilda Stories), are cast in the maternal roles of nurturers, protectors and mentors. Most of the foremothers and "grannies" in historical and heritage maternal romances, including Mama Day, Pilate, Aunt Cuney, Miss Matie, Vyry and Nanny, take the "biologic poetics" one step further. They are iconic figures of cultural continuity, resistance and female struggle for social justice, described by Rody as "ancestral guides of a more spiritual kind," who do not always "privilege conventional motherhood," but instead take pride in "the spiritual role of mother of a nation" (The Daughter's Return 97).

Friedman's criticism is crucial to my thinking about the volkish tradition that elevated one (womanist) kind of text and one (matrilineal) formula for female empowerment. As Hazel V. Carby argued in Reconstructing Womanhood: The Emergence of the Afro-American Woman Novelist (1987), biological poetics obscured other cultural traditions, such as the 19th century novel of passing. ${ }^{81}$ It created a womanist histori-

81 See also: Ann duCille's The Coupling Convention: Sex, Text, And Tradition in Black Women's Fiction (1993); Deborah McDowell's “The Changing Same”: Black Women's Literature, Criticism, and Theory (1995); and Claudia Tate's Domestic Allegories of Political Desire: The Black Heroine's Text at the Turn of the Century (1996). Audre Lorde commented that "Black writers ... who step outside the pale of what 
ography of African American letters that started with female slave narratives and the anthropological writings of the foremother Zora Neale Hurston. In her essay, "Revolutionary Black Women: Making Ourselves Subject," bell hooks criticizes this simplified and linear, womanist literary canon for its "potential to repress and contain" (221). She condemns Michelle Cliff, among other writers, for glorifying in her essays the black women writers who created the womanist/volkish canon (ibid.). hooks quotes at length the following passage from Cliff's essay, "Women Warriors: Black Writers Load the Canon," in which she analyses the source of "the power of black women's writing":

There is continuity in the written work of many African-American women, whether writer is their primary identity or not. You can draw a line from the slave narrative of Linda Brent to Elizabeth Keckley's life to Their Eyes Were Watching God to Coming of Age in Mississippi to Sula to The Salt Eaters to Praisesong for the Widow. All of these define a response to power. All structure that response as quest, a journey to complete, to realize the self; all involve an attempt to break out of expectations imposed on black and female identity. All work against the odds to claim the I. (Cliff, qtd. in hooks ibid.)

According to hooks, "passionate declarations like this one, though seductive, lump all black female writing together in a manner that suggests there is indeed a totalizing telos that determines black female subjectivity" (ibid.). They construct a "master narrative" that promotes "a homogenous black female subject whose subjectivity is most radically defined by those experiences she shares with other black women” (ibid.). hooks contends that "the wonderful experience of sisterhood and black-woman bonding" was unfortunately more often than not used by writers and womanists to “"[police] ... anyone who [did] not conform” and to censor those black women who wished "to speak an identity from a different location" (ibid. 219).

hooks claims that as a result of this approach, the BWR lacked "honest" books on "mothering, on sexuality, on feminist film criticism" (ibid. 232). She asks: "Where are our autobiographies that do not falsely represent our reality in the interest of promoting monolithic notions of black female experience or celebrating how wonderfully we have managed to overcome oppression" (ibid.)? In her opinion, "honest confessional narratives by black women" played an important part in African American literary history and were still badly needed at the turn of the century in order "to understand the complexity and diversity of black female experience" (ibid. 233). Instead, womanist fiction, based on Walker's certainties about black culture, presented a false sense of unity and urged black women to embrace this model of black womanhood alone. In

writers are supposed to be, are [sometimes] condemned to silences in black literary circles that are as total and destructive as any imposed by racism" (Tate, “Audre Lorde” 101). Popular writers who have been excluded by the womanist tradition include Terry McMillan, Sapphire (Ramona Lofton), Bebe (Elizabeth) Moore Campbell, Sister Souljah (Lisa Williamson). 
effect, hooks contends, womanism was counterproductive to the goals of black feminism and thwarted black women's ambition to become iconoclastic radical subjects. She denounces all of Michelle Cliff's novels, arguing that none of them is successful in inventing a radical black subjectivity that "works against the odds to claim the I" (Cliff, qtd. in hooks 221), as Cliff put it. hooks's argument can easily be extended to the BWR novels of the 1980s, whose narrators did not look kindly on their heroines' attempts to venture beyond the tribal fold. Class-conscious and upwardly mobile Jadine, Kitty (Clare's mother), Avey and Silla are presented as flawed and inauthentic daughters or mothers.

The matrtifocal writing of womanism, with its "gender-coded politics of recognition" (Fraser, "Mapping” 300), was like a cultural "smokescreen" that sought to conceal psychological, generational and class differences among black women (White, “Africa on My Mind” 135). Like BCN's reminiscences about the golden days of the ghetto, this writing promoted nostalgic notions of segregated southern communities. According to Dubey, it was a "dangerous [kind] of political work ... used as a [stick] with which to beat the black urban poor” (Signs and Cities 238). It also ushered in conservative notions of black womanhood that stifled internal dissent, especially with regard to black women's roles. E. Frances White suggests that as womanist volkish writing became entrenched, "the power of the older women over younger women ... [became] idealized as a vision of the elders' wisdom in decision making" ("Africa on My Mind" 145). Putting it differently, she said that matrifocal womanist romances "accept[ed] the view of age relations presented by more powerful older women whose hidden agenda [was] often to socialize girls into docile daughters and daughters-in-law" (ibid.).

The majority of BWR writers stand in judgment over their female characters who, like Jadine, Kitty and Avey, defect from the nationalist and matrilineal project. They are unwaveringly single-minded in insisting that maternity is a site of female power, and that the volkish tradition is indispensable for the survival of the "nation." By contrast, the novels of Kincaid problematize the conflation of mother and nation, and challenge the "nurturing 'motherland' myth" (Boehmer, Stories of Women 15). Unlike African American writers, African Caribbean women authors are not so consistent in picturing domestic hearths and southern/Caribbean folk communities as the sites of reproduction of essentialist female black cultures. And even though they exhibit the anthropological longing for cultural roots that the motherland myth designates, they nonetheless dramatize the impossibility of fulfilling this obsessive desire. Their narratives represent the historical, cultural and generational ruptures that are characteristic of the experiences of diasporic black women. For example, Marshall and Lorde expose the asymmetries of power in the motherdaughter dyad and address generational gaps in women's outlooks on the issues of gender, sexuality and class. Their fiction does not gloss over conflicts and divergent interests among different groups and generations of black women or naturalize them by focusing on cultural alliances between mothers and daughters. By representing 
cultural and psychological conflicts, these writers counter, to a greater or lesser extent, the "ethnographic approach" of African American matrifocal historical fictions and debunk the illusion of the unbroken generational continuity of diasporic African cultures.

The novels by Cliff and Kincaid, in particular, constantly underline the "shifting and variable process of creolisation" (Glissant, Caribbean Discourse 15). In spite of Cliff's efforts to valorize matriliny, the Clare Savage novels inadvertently document the decline of an idea that grounds female activism in the myth of the great foremother Nanny. They also betray a sense of nostalgia for the irretrievable loss of the indigenous histories, cultures and identities that were obliterated by slavery and colonization. Kincaid, on the other hand, makes the best of the historical and ontological void caused by uprooting and displacement to negotiate the newness of her situation in her own terms. In her autobiographical fiction, exile makes possible the dissolution of class, race, and gender boundaries and offers alternatives to conventional gender roles. For Annie John and Lucy, migration offers the promise of enhanced possibilities to reinvent themselves free from patriarchal or nationalist dictates and the controlling “colonizing” gaze of older women. As Kincaid's young women resist rigid patterns of socialization and being co-opted to preconceived essentialist cultural formations, they become the "radical black subjectivities" that bell hooks searched for, but did not find, in the mainstream BWR fiction.

I believe there is strong rationale for comparative reading of African American and immigrant African Caribbean authors. On the one hand, there are fundamental areas of consonance between their historiographical projects and the ways in which they use the allegory of motherhood to talk about the negative heritage of New World slavery and colonization. What connects these writers is primarily their adoption of similar tropes: namely, the link between women and culture; the theme of the motherland(s); and their engagement with the difficult heritage of African people in the New World. On the other hand, however, their outlook and the internal dynamics of their novels are very different. Whereas African American writers drew on their ethnic cultural reserves to construct a strong and authoritative communal voice in order to combat misrecognition and misrepresentation, writers of Caribbean descent fell back on the ideology of ethnic particularism less frequently. For example, while Lorde's and Marshall's texts recover and recreate African spirituality and myths, in social and psychological terms, these writers generally depict the intersectional conflicts that undermine the black nationalist/womanist insistence on unity. Cliff's narratives openly tackle the painful disinheritance of black people that Walker and other womanists were at pains to conceal. Unlike womanist texts, the Clare Savage novels do not lend themselves to any overoptimistic and redeeming readings. Similarly, Kincaid's idiosyncratic, irreverent and provocative writing stands as a categorical refusal of any form of biological, gender or racial essentialism.

In an interview with Moira Ferguson, Kincaid described the huge gulf she perceived between her own attitude to race, culture and writing and that of the BWR, 
giving an interesting explanation of African Americans' propensity to adopt a politics of racialised culturalism:

I don't think that American [black] women have much that we [Caribbean women] can draw from. I mean the use of language is very different, and their concerns are much different. A much different sensibility. For instance, I think that American black people seem to feel almost that being black is a predestination in some way. They have a kind of nationalism that we don't have; black nationalism. Because they are a minority, they are concerned with their identity being extinct, whereas we don't feel that way. Everybody is black. I mean we don't think that white people are permanent. We don't feel permanent either, but that feeling of "there will always be white people sitting on top of black people” - we don't have ... Black nationalism in this country [the USA] is very much because there is an acceptance, in some way, of how the majority of the population have thought about black people. There is very much internalization of that. Why else have "black pride"? I mean there is no reason to be particularly proud of something you can't help. It's not an effort you made and you became black. It is just the way you are. There is nothing particularly pleasing or displeasing about it. (Ferguson, "A Lot of Memory" 164)

While I think that more common threads run through African American and African Caribbean literary traditions than Kincaid cares to admit, her apt comments elucidate the divergent ways in which African American and African Caribbean women writers approach the essentialist and regulatory politics of cultural nationalism and the history of the African diaspora in the New World.

This divergence is conspicuous in these writers' attitudes to the slave past and its contemporary legacy. While the African Caribbean narratives of Cliff and Kincaid do address the importance of remembering, and take issue with the cultural amnesia experienced by assimilated diasporic Africans, they are generally less concerned than African American writers of the BWR with the dim and distant slave past and are totally oblivious to the rhetoric of the slave sublime. Their work is also more persistently focused on the politics of redistribution, an issue that was sidelined by womanism. African Caribbean writers also more frequently tackle the recent history of neo-liberal exploitation. For example, Audre Lorde in "Grenada Revisited" and Jamaica Kincaid in A Small Place and Lucy address the subject of American imperialism; and Paule Marshall in The Chosen Place, The Timeless People and Michelle Cliff in No Telephone to Heaven deal with the issue of neo-colonialism. These writers resist the idea that a shared traumatic heritage of slavery unites all blacks into a distinct and exceptional "people.” Slavery, the Middle Passage and the indignities of the colonial system are represented as the origin of postcolonial economic and social malaise, but none of these four writers uses what Paul Gilroy has called "memory work" to build a memory-centered ethnic/national community (The Black Atlantic 55). Nor does their writing attempt to transpose the tragedy of enslavement into an edifying message for humanity. Slavery and colonization are, first and foremost, important progenitors of racism and neocolonial deprivations; they are not stripped of their material ramifications or configured as sublime experiences that exist in the sanctified and elevated realm beyond understanding, language or representation. 
With the exception perhaps of Paule Marshall, the African Caribbean writers discussed in this monograph do not invest so much in the practice of "textual healing" as the narratives of immersion and neo-slave narratives do. I borrow the term "textual healing” from Thorsson, who draws on Farah Griffin to argue that in BWR prose the healing takes place in black female bodies that are presented not only as "sites" of "pleasure and resistance" in their own right, but also as the victimized and "scarred" consciousness of African America as a whole (Griffin, qtd. in Thorsson, Women's Work 37). Novels such as Jubilee and Beloved, for example, use the female body as a metaphor for the national body politic, illustrating what the process of textual healing is about. Griffin sums this up by saying that "[t]he body can never return to a prescarred state," and so the healing "is not a matter of getting back to a truer self, but instead of claiming the body, scars and all - in a "narrative of love and care" (ibid.). As this remark implies, textual healing is both a corporeal and a psychological process but also a historical and revisionist practice in which historical discourse is used "to move from individual to nation ... Just as the body must be claimed 'scars and all', so the African American nation must be built by claiming its usable past, including the wounds of racial and gendered oppression, into a 'narrative of love and care that can heal and define the communal as well as individual body" (Griffin, qtd. in Thorsson 37-38). Healing was, therefore, a "movement from individual bodies to psyches to communities" (Griffin, qtd. in Thorsson 38). Textual healing put women writers at the center of the national imaginary as conjurers capable of "inscribing a national destiny into time and injecting new life into ... myths of the past” (Boehmer, Stories of Women 11). It allowed African American writers of the BWR to claim the experience of the whole "nation" in order to assert themselves against the oppressive dominant culture and polity. Textual healing was also a cultural "treatment." Gabbin notes that it "[drew] upon a rich legacy of storytelling and myth-making" ("A Laying on of Hands" 246), and Thompson suggests that folk rituals were "the real medicine" that served the purpose of "debunk[ing] years of negative programming in the media" and "reconnecting [black women] with [their] past, with [their] roots" so that they could "affirm [them] selves holistically, psychologically, and spiritually" ("The Power").

On the other hand, however, the concept of textual healing could also be seen as having a somewhat "supremacist" tendency towards both the oppressors and those black people who, like Crouch, wanted to let go of the past. As Sandoval suggests, it endowed BWR writers with the power to "assert that those [racial and cultural] differences have provided them with a superior level than those currently in power" ("U.S. Third World Feminism” 13). By claiming their oppression, "scars and all” (Griffin, qtd. in Thorsson, Women's Work 37) through heroic narratives of trauma and redemption, perseverance and survival, immersion and healing, the writers of the BWR assumed a higher moral ground from which they demanded recognition for their painful histories and denigrated cultures and respect for their civil rights. Like Jewish discourse about the Holocaust, the rhetoric of the slave sublime conferred on their "people," or "tribe," a sense of nobility and pre-eminence that fed into the conviction of African 
American exceptionalism. In addition, the efforts of the BWR to raise consciousness about the slave past, and particularly about black women's oppression, created not only a "shared tradition" but also a "coercive common destiny," to quote Elleke Boehmer out of context (Stories of Women 11). According to bell hooks, BWR fiction was almost exclusively about black women's suffering and resistance, and their need for healing. She suggested that this fiction gives the impression that female writers at the time of the Renaissance were in "doubt that there [was] an audience for fictions where black women are not first portrayed as victims" ("Revolutionary Black Women" 224). Indeed, the frequency with which the idea of textual healing recurs in BWR fiction of the 1980s was unnerving for several African American writers and critics, including not just bell hooks but also the aforementioned E. Frances White and Stanley Crouch. Charles Johnson, whose criticism of the "deadly sameness" of neo-slave narratives was quoted earlier, also advocated that black authors should try to get over their "tendency to plow the same racial and social ground over and over when an entire universe of phenomena lay waiting for investigation" (Being and Race 119).

For hooks, the only BWR author who was successfully transcended the "racial and social ground," was Toni Cade Bambara. hooks describes Bambara as being among the very few truly revolutionary black women who dared to "assert nonconformist politics and habits of being," 82 to "decolonize minds," and to develop a more "critical consciousness" ("Revolutionary Black Women” 233). For me, Bambara's novel, The Salt Eaters, is an uncommonly enlightening and entertaining take on the "textualhealing" approach of BWR fiction and other excesses of the womanist/volkish tradition. As Dubey notes, like most womanist novels, this narrative handles the "issues of ancestry, conjuring, oral tradition, ... [and] the South...," but Bambara does not "offer readers the fix of tribal values or aestheticized racial difference" (Signs and Cities 237). The novel presents, in a realistic manner, a culturally and ethnically diverse community, in which Puerto Rican, Chicana and African American women "[share] not only a common condition but also ... a common vision about the future" (Guy-Sheftall, "Commitment” 239). In this way, as Carter Mathes has stated, "Bambara’s writing suggests conceptions of late-twentieth-century racial subjectivity that embrace the seeming chaos of multiplicity and interconnection, not as an erosion of particular identities and locations, but rather as crucial starting points for the realization of the political complexity within them" ("Scratching the Threshold” 370). Bambara's novel does not glorify ethnicity, and flatly refuses to romanticize the South as a place where, in the words of Walker, one "feel[s] the soil between the toes, smell[s] the dust thrown up by the rain, lov[es] the earth so much that one longs to taste it and sometimes does" ("The Black Writer" 21). Bambara's South is not a magical place of spiritual immer-

82 Other writers who are placed in this category by hooks include Gloria Joseph, Faye Harrison, June Jordan and Angela Davis. 
sion but a real place affected by racism, sexism, poverty and environmental destruction, as symbolized by the Claybourne Transchemical Plant. Against this backdrop, Bambara presents the process of spiritual healing of a black female activist, Velma, who had had a nervous breakdown that led her to attempt suicide.

Spread thin by "them dead moments alive," memories of past suffering, lost opportunities and defeats (The Salt Eaters 22), Velma is an embodiment of the shared history of black female oppression. But it soon transpires that the process of healing Velma's traumatized psyche is not so much about laying a claim to "scars and all" as about giving "the right amount of weight" to these "dead moments," so that she does not completely give in to what the novel presents as unnecessary and self-indulgent suffering. Velma's pain is contextualized through the folk myth about captured Africans who had swallowed so much of the salt in their tears that they lost their ability to fly and break free from slavery. Bambara has commented that as "some of the folks say, we got grounded because we open ourselves to horror ... that created tears. And it was that salt that drowned our wings and made us earthbound" (Bonetti, "An Interview"). Thus, according to Bambara, while it is important to absorb just the right "amount of salt," the source of Velma's problem is that she obsessively dwells on the horrors of the past. Bambara believed that "there is no future without memory," as did all of the writers of the BWR, but at the same time she emphasized the need to glance "both ... back ... as well as flash forward" (ibid.). Minnie Ransom, the healer of Velma and other "salt eaters," is, therefore, "mostly future-oriented," like Bambara herself. What Minnie thinks about her patients could just as well be applied to most BWR writers and their female protagonists:

They wore the crippleness or blindness like a badge of honor, as though it meant they'd been singled out for special punishment, were special. Or as though it meant they'd paid some heavy dues and knew, then, what there was to know, and therefore, had a right to certain privileges, or were exempt from certain charges, or ought to be listened to at meetings. (The Salt Eaters 108)

It does not make any difference that "way down under," these women knew that “"special' was a lie" (ibid.). They were "so used to being unwhole and unwell” that they "forgot what it was to walk upright and see clearly, breathe easily, think better than was taught" (ibid.). As a remedy for their metal afflictions and a way to become "well" again, Minnie counsels her patients to let go of the past and "stride into the future sane and whole" (ibid.). The alternative - the belief "that it was safer to live with complaints [and] ... necessary to cooperate with grief" - was, in her opinion, tantamount to "becom[ing] an accomplice in self-ambush" (ibid. 107).

Admittedly, by laying claim to historic suffering and victimization, BWR writers were rightly expressing their rage at the national lack of concern for the African American history of oppression and for the plight of black people in the extreme sociopolitical conditions of the 1980s and 90s. However, as bell hooks has pointed out, "the intensity of ... [that] struggle, [and] the fear of failure" led womanist writers "to 
wrongly assume that strength in unity can only exist if difference is suppressed and shared experience [of oppression] is highlighted" ("Revolutionary Black Women" 226). The sense of righteousness that BWR writers felt was, as Patricia Hill Collins has stated, grounded in "claims of moral superiority ... because of black suffering" ("What's in a Name?" 10). However, it gave rise to what Trinh T. Minh-ha has described as an "essentialist hegemony" ("Not You/Like You” 416), or even a matrix of hegemonies. The principal hegemony of the volkish tradition, namely "[t]he prevalence ... of the focus on relations between women and the 'tribe' (mothers, daughters and grandmothers)" (Rhonda Cobham, qtd. in John, Clear Word 57), was matched by the equally hegemonic paradigm of the textual healing of the female and national body. This assumed that "the reality of women's oppression is ... shared by all women who are perceived to constitute a basically homogenous social grouping with the same interests" (Yuval-Davis, Gender \& Nation 119). Thus, in the name of "an implied stability, an internal coherence," womanist writing and criticism "neutralized" tensions among black people and forged instead "affective affiliations" based on common roots and common oppression (McDowell, “The Changing Same” 20).

It is interesting to see what tensions these affective affiliations helped to hide, and to note that these tensions were not resolved in either the creative writing of the BWR or the discourse of black feminism. Speaking about feminist movements in general, Yuval-Davis has argued that building affective affiliations, or, in other words, creating dominant discourse, is in the interest of "those [women] holding the hegemonic power within the movement” (Gender \& Nation 119). Indeed, feminists often use the technique of "consciousness rising" to delegitimize the voices of those women who, as bell hooks has put it, want to "to speak an identity from a different location" ("Revolutionary Black Women” 219). Consciousness-raising was "the backbone of the [feminist] movement and a chief organizing tool." ${ }^{83}$ However, in Yuval-Davis's opinion, it allowed activists to split women into two groups: the knowledgeable leaders, who were politically and socially aware; and the followers, whose level of self-consciousness was regarded as low. She maintains that this maneuver made it easy to sidestep differences among women and explain them "as mainly reflections of different stages of raised consciousness” (Gender \& Nation 119). Thinking further about who wielded this hegemonic power in the black feminist movement in the 1980s, it is fairly clear that the feminists who, in Bambara's words "ought to be listened to at meetings" (The Salt Eaters 108), were the figures such as Alice Walker, Toni Morrison and Michelle Cliff. As a Marxist feminist critic, bell hooks saw the feminist technique of "consciousness raising" as a means of constructing a "particular brand of black feminist essentialism” whose hidden agenda was to fix attention on culture,

83 Feminist Consciousness-Raising Groups. Collective Action through Discussion. April 26, 2017. https://www.thoughtco.com/feminist-consciousness-raising-groups-3528954 
history and oppression rather than on the problem of class stratification and the concomitant disempowerment of the lower classes ("Revolutionary Black Women" 219).

In this way, cultural nationalism in the black feminist movement (and in black creative writing), with its focus on cultural representation and the negative heritage of slavery and colonialism, became a sort of "smokescreen" between people and reality, to misquote E. Frances White (“Africa on My Mind" 135) ${ }^{84}$ While Fraser thought that feminism had unconsciously fallen for the trap of culturalism, hooks and White, conversely, suggested that the end-of-the-century cultural turn in black feminism was an expedient way for black writers and feminists to construct "subordination" as "a problem of culture ... [that was] dissociated from political economy" (Fraser, "Mapping 299) and to hide the ambivalent relationship between well-to-do elites and the black precariat. The uneasiness with which BWR writers and critics tackled the issues of social mobility, wealth acquisition and western education (vs folk ways of knowing) speaks volumes, I think, about their anxiety about their black middle-class identity. Caught between class and race loyalties, BWR feminists and critics tried to resolve the ideological contradictions in their position by replacing economism with culturalism that was expressed through their passion for the folklore and tragic history of African America. As bell hooks has observed, the writers, critics and feminists of the BWR were "[o]ften professional black women with academic degrees," and many of them "[were] quite conservative politically. Their perspectives differ[ed] greatly from our foremothers, who were politically astute, assertive, and radical in their work for social change" (Talking Back 181). In hooks's opinion, the preoccupation of the BWR with ethnicity, cultural roots and slavery actually discouraged black women from "thinking critically," and, not surprisingly, led the BWR to distance itself from "all efforts to engage with leftist or socialist ideas" which middle-class feminists wanted to sideline ("Revolutionary Black Women” 232).

In "Revolutionary Black Women," hooks gives an account of how coercive the "black feminist essentialism" of the 1980s could be when it came to discussing different experiences of being black and female. She also explicitly links the regime of black feminist essentialism to privileged, middle-class, feminist colleagues. hooks describes a feminist gathering, during which the topic of black female victimization had come up. She recalls being "chastised" by one of her "famous" black colleagues for saying that she did not feel victimized and being accused of "trying to erase another black woman's pain by bringing up a different experience” (219). It seemed, claims hooks, that "the cathartic expression of collective pain wiped out any chance that my

84 These discourses: cultural nationalism in creative writing and black feminism are similar to the dominant discourses that are also based on misrepresentation (e.g. orientalist discourses), or negative images (e.g. images that equate Africa with AIDS, famines, civil wars, corruption, child soldiers, huts, FGM - female genital mutilation and slums). All of them are "closely tied to the socioeconomic and political institutions that enable oppressive relations" (White, "Africa on my Mind” 135). 
insistence on the diversity of black experience would be heard" (ibid.). It appeared to hooks that "the black female voice that was deemed 'authentic' was the voice in pain; only the sound of hurting could be heard" (ibid.). According to hooks, the essentialist black feminists at that gathering tried to suppress difference by exhibiting "collective black female 'rage' [...], the anger directed at individual black women who dared to speak as though [they] were more than [their] pain, more that the collective pain black females have historically experienced" (ibid. 220). bell hooks, together with some other participants who dissented from this view, "left with a sense of estrangement" feeling that "[to] speak against the grain was to risk punishment” (ibid. 219).

hooks then contrasts that experience with a gathering of the Council for Battered Women, whose participants were not "famous" black colleagues, but ordinary black women, whom bell hooks tellingly calls her "comrades." She emphasizes the fact that there was a marked difference between these two meetings that were attended by women from different social backgrounds. At the Council for Battered Women's meeting, she says the women were working "collectively [...] to problematize [their] notions of black female subjectivity. None of [them] assumed a fixed essential identity. It was so evident that [they] did not share a common understanding of being black and female, even though some of [their] experiences were similar" (ibid. 220). She adds that any woman could speak out without fear of being censured or accused of trying to "construct radical subjectivity within white supremacist capitalist patriarchy" (ibid.). For hooks, it was clear that radical black subjectivity should be informed by critiques of cultural misrepresentation, sexism and capitalist oppression.

I would like draw this study to a conclusion by pointing out that contemporary black feminism is in the vanguard of creating what Fraser has called "a broader and richer paradigm that could encompass both retribution and recognition" that is concern with economic and cultural oppression ("Mapping" 300). The work of deconstructing the "totalized, unitary definition" of black womanhood had already begun with what Deborah McDowell has described as the "'paradigm shift' [in the late 1980s], from the 'Age of Criticism' to the 'Age of Theory"' ("The Changing Same” xi). Informed by poststructuralist theories, black feminist critics like McDowell and Hazel Carby set out to abolish the form of literary criticism practiced by womanist critics such as Barbara Smith, whose work McDowell accused of offering "political persuasion" that was aimed at forging deceptive "affective affiliations" among black women (ibid. 9). These post-structuralist critics shed light on how nationalist ideology was informing critical analysis in such a way as to create "solidarity from a sense of particularity” (Gilroy, qtd. in McDowell, ibid. 19). They exposed the literary criticism of the 1970s and '80s as being, in McDowell's words, "another form of storytelling, of mythmaking," a highly politicized and affective discourse whose aim was to determine "what ... [readers] see when they read and how they receive and represent what they read" (ibid. 118).

The intersectional analysis that emerged at around the same time went beyond the "theoretization of identity" to highlight interlocking systems of oppression, not only 
the racism that had necessitated the struggle for cultural recognition, but also sexism and classism. The new intersectional methodology, which was associated with the work of Kimberlé Crenshaw, ${ }^{85}$ bell hooks, Patricia Hill Collins and the Chicana feminists Cherríe Moraga and Gloria Anzaldúa, considered complex relations of domination and subjugation in American society and within the black "nation." It delineated a "matrix of domination" (Collins, "Black Feminist Thought" 221), which was developed from bell hooks's earlier theory of the "politics of domination." ${ }^{86}$ Collins defines the matrix of domination as "an over-reaching structure of domination" made of three "interlocking systems of oppression," namely race, gender and class (ibid. 222). These systems of oppression can affect different groups of people: women in general, colored women in particular, the LGBT community and workers, all of whom can be subjected to one or more systems of oppression at the same time. As Collins observes, however, whereas "most individuals have little difficulty identifying the sources of their own victimization within some major system of oppression - whether it by race, social class, religion, physical ability, sexual orientation, ethnicity - they typically fail to see how their thoughts and actions uphold someone's else's subordination" (ibid. 287). What Collins's theory implies is that in different contexts the same person may turn from the oppressed into an oppressor, as, for example, within the black feminist movement, where middle-class feminists used the philosophy of consciousness rising to repress other women's experiences and voices.

Intersectional analysis, which is glaringly absent from Nancy Fraser's analysis of the trajectories of late 20th-century feminism, replaced the flawed womanist theory and did a lot to rectify what Fraser, in called "mis-framing." She defines mis-framing as "partition[ing] the political space in ways that block many who are poor and despised from challenging the processes that oppress them" (304). While Fraser uses the term to talk about the compartmentalization of feminisms by nationality "frames" and calls for the "re-framing" of feminism as an international movement, it is clear that in the latter part of the 20th century in the US, mis-framing also operated at an ethnic level and within the politics of multiculturalism. Mis-framing can therefore

85 Kimberlé Crenshaw is credited with coining the term in 1989, but the original concept was developed by the sociologist Beatrice Potter Webb in 1913. See Kimberlé Crenshaw’s “Demarginalizing the Intersection of Race and Sex: A Black Feminist Critique of Antidiscrimination Doctrine, Feminist Theory, and Antiracist Politics."

86 It should be noted that these two critics were frequently at odds with each other. In her interview with Paul Gilroy in Small Acts, bell hooks criticizes Patricia Hill Collins, an Afrocentric black feminist critic, and her study, Black Feminist Thought: Knowledge, Consciousness and the Politics of Empowerment, as a book that "doesn't challenge that [traditional and conservative] construction of family and home at all” (Gilroy, “A Dialogue with bell hooks” 232). They did, however, agree about the intersection of various forms of oppression. See Patricia Hill Collins's "Black Feminist Thought in the Matrix of Domination," in Black Feminist Thought: Knowledge, Consciousness, and the Politics of Empowerment. 
also be understood not just as the partitioning of feminism into womanist, black, yellow and red feminisms, but also, I think, as the analysis of different forms of female oppression such as racism, classism and sexism in isolation. In fact, intersectionality allowed feminism to be to "re-framed" by offering new ways of reading class, race and ethnicity, thus making it possible to synthesize the concern with economic and cultural oppression. Like the theories of feminist researchers of nationalism and poststructuralist feminism, intersectional analysis is a useful conceptual tool that allows us to see BWR fiction of the 1980s for what it really is: namely, an elaborate effort to regenerate the imagined black community from within; an ambitious nation-building enterprise, in which black women are made the principal agents/carriers of national identity; and, in the final analysis, an inevitably flawed project that replicated all the problematics of the nationalist ethos, including its gender essentialism, its denial of class stratification, and its tendency to adopt a "rigid set of aesthetic orthodoxies" (McDowell, "The Changing Same” 50). 